\title{
SPECTROSCOPIC AND POROSIMETRIC ANALYSES OF ROMAN POTTERY FROM AN ARCHAEOLOGICAL SITE NEAR MOŠNJE, SLOVENIA
}

\author{
SPEKTROSKOPSKE IN POROZIMETRIČNE PREISKAVE RIMSKE \\ LONČENINE Z ARHEOLOŠKEGA NAJDIŠČA PRI MOŠNJAH, \\ SLOVENIJA
}

\author{
Sabina Kramar ${ }^{1}$, Judita Lux ${ }^{2}$ \\ ${ }^{1}$ Slovenian National Building and Civil Engineering Institute, Dimičeva 12, 1000 Ljubljana, Slovenia. \\ 2Institute for the Protection of Cultural Heritage of Slovenia, Centre for Preventive Archaeology, Tomšičeva 7, 4000 Kranj, Slovenia \\ sabina.kramar@zag.si \\ Prejem rokopisa - received: 2014-07-16; sprejem za objavo - accepted for publication: 2014-07-31
}

doi: $10.17222 /$ mit. 2014.110

\begin{abstract}
This study deals with spectroscopic and porosimetric analyses of pottery from a Roman villa rustica near Mošnje, Slovenia. Samples of coarse ware and fine ware, which according to archaeological considerations have been recognised as local or perhaps regional products, were investigated using FTIR spectroscopy, scanning electron microscopy, mercury-intrusion porosimetry and gas sorption. Based on their FTIR spectra, the pottery sherds can be divided into two main groups, depending on the presence or absence of calcite. The firing temperature was estimated according to the presence of an absorption band at around $3630 \mathrm{~cm}^{-1}$, associated with hydroxyl groups of minerals that are persistent up to $800{ }^{\circ} \mathrm{C}$. The differences among the coarse and fine ware sherds related to the pore morphology and the pore volume in the matrix were observed, as was the extent of the vitrification. In general, the total porosity of the pottery sherds with coarse-grained calcite inclusions was lower than that of the fine pottery sherds. The fine ware samples also exhibited a significantly higher BET surface area than the coarse ware samples.

Keywords: Roman pottery, archaeological ceramics, FTIR, porosimetry, Mošnje

V prispevku so predstavljeni rezultati spektroskopskih in porozimetričnih analiz lončenine iz rimske vile rustike pri Mošnjah (Slovenija). Vzorce grobe in fine keramike, ki naj bi bila glede na arheološke raziskave lokalnega ali regionalnega izvora, smo preiskali s spektroskopijo FTIR, vrstično elektronsko mikroskopijo, živosrebrovo porozimetrijo in plinsko sorpcijo. Glede na spektre FTIR lahko lončenino razdelimo v dve skupini, odvisno od tega, ali vsebuje kalcit. Temperatura žganja je bila ocenjena glede na prisotnost absorpcijskega traku hidroksilnih skupin pri okoli $3630 \mathrm{~cm}^{-1}$, ki je obstojen do $800{ }^{\circ} \mathrm{C}$. Med grobo in fino keramiko so opazne razlike $\mathrm{v}$ obliki in volumnu por ter obsegu vitrifikacije. Na splošno je celotna poroznost lončenine $\mathrm{Z}$ dodatkom debelozrnatega kalcita nižja kot pri fini keramiki. Slednja ima v primerjavi z grobo keramiko tudi občutno višjo specifično površino BET.

Ključne besede: rimska lončenina, arheološka keramika, FTIR, porozimetrija, Mošnje
\end{abstract}

\section{INTRODUCTION}

Analyses of the potteries that represent one of the most abundant types of archaeological find reveal information regarding the daily life and culture of ancient societies. ${ }^{1,2}$ The mineralogical and chemical characterisation of pottery provides evidence for the technology involved in the manufacturing process and potentially the provenance of the raw material used. ${ }^{3-6}$ Besides the raw materials, the nature and quality of the pottery depend on the firing temperature, the firing atmosphere or the kiln conditions, as well as the technical skill of the potter. ${ }^{7}$

Thermal transformations in clay materials during firing provide a means with which to estimate the firing temperature of the artefacts. ${ }^{8}$ FTIR spectroscopy is considered as an important tool in the analysis of clay minerals and mineral transformation due to thermal effects, with the infrared spectra of the pottery revealing both the type of clay and the firing temperature. ${ }^{8-10}$ An SEM examination of the pottery provides information regarding not only the internal morphology that developed during the original firing in antiquity, but also the extent of the vitrification (the glassy phase) and the pore structure. ${ }^{11,12}$

Porosity is a fundamental attribute of pottery and can provide information about many aspects of archaeological manufacturing technologies, including the firing temperature, the type of clay and tempering materials, and the manufacturing and forming techniques employed, which all contribute to the degree of ceramic porosity exhibited. ${ }^{13}$ Porosity also influences a wide range of ceramic use-related properties, such as strength, permeability, thermal insulation, as well as resistance to abrasion and thermal shock. ${ }^{14}$

Most pottery sherds found at the archaeological site near Mošnje, Slovenia date from the Augustian period (27 $\mathrm{BC}$ to $14 \mathrm{AD}$ ) to the $2^{\text {nd }}$ Century, thus providing additional confirmation that the Roman villa rustica was built in the first half of the $1^{\text {st }}$ Century and was in use 
until the end of the $2^{\text {nd }}$ Century, at the latest. The discovery of pottery fragments dating to prehistory, together with a number of bronze finds from the Early and Late Iron Ages, indicates settlement of the area prior to the arrival of the Romans. Furthermore, the presence of Late Roman pottery on the site that confirms the continuity of settlement somewhere nearby the villa, which by this time had already been abandoned.

It is widely known that both coarse ware and domestic tableware are usually of local manufacture and that such forms are typically not chronologically very sensitive. ${ }^{15}$ The selected pottery samples, which according to the archaeological analysis have been recognised as local or perhaps regional products (i.e., not imported/terra sigillata), differ in their mineralogical and chemical composition, reflecting a variation in the manufacturing technology and the type of clay material used. ${ }^{16,17}$ The sherds were classified into two distinct groups: (i) Group 1 - sherds made from clay with a high plasticity (calcite-tempered ware), containing abundant calcite and smaller amounts of quartz; (ii) Group 2 sherds with a predominantly fine silicate fabric, part of the original clay, calcite-free and containing abundant quartz and illite/muscovite. Group 1 sherds are fairly homogenous, indicating that the technology of manufacture changed only slightly with time. The mineralogy and geochemistry of these sherds are also similar, suggesting that they must have been produced from the same source of raw materials, although the greater amount of quartz observed in two Late Roman sherds suggests a possible different clay-mass source in use at this time. In contrast, the Group 2 samples are highly heterogeneous, indicating the use of various sources of raw materials.

In the present study, samples of Roman coarse ware and fine ware from the archaeological site of Mošnje were chosen for spectroscopic and porosimetric analyses. FTIR spectroscopy, scanning electron microscopy, mercury-intrusion porosimetry and gas sorption were applied in order to characterise the porosity and estimate the firing temperature of the pottery.

\section{EXPERIMENTAL}

\subsection{Materials}

Seven samples - four of coarse ware and three of fine ware - previously studied with respect to their mineralogical and geochemical characteristics ${ }^{16,17}$ were selected for the investigation. Information regarding the microlocation, type, surface colour and probable date of the pottery samples is provided in Table $\mathbf{1}$.

\subsection{Methods}

Samples were analysed via Fourier-transform infrared spectroscopy (FTIR) using a Perkin Elmer Spectrum 100 spectrometer. Sixty-four signal-averaged scans were acquired. Powder pellets were pressed from a mixture of sample and $\mathrm{KBr}$ at a ratio of about $1: 200$. The FTIR spectra were recorded with a spectral resolution of 4 $\mathrm{cm}^{-1}$ in the range $4000-400 \mathrm{~cm}^{-1}$.

Freshly fractured surfaces of the pottery as well as polished thin sections were examined using the back-scattered electron (BSE) image mode on a scanning electron microscope (SEM) at low vacuum (between 10 $\mathrm{Pa}$ to $15 \mathrm{~Pa}$ ), coupled to an energy-dispersive X-Ray (EDS) analyses, using JEOL 5500 LV equipment.

The pore systems of the samples were further investigated by means of mercury-intrusion porosimetry (MIP) and gas-sorption isotherms. Small representative fragments, approximately $1 \mathrm{~cm}^{3}$ in size, were dried in an oven for $24 \mathrm{~h}$ at $105{ }^{\circ} \mathrm{C}$ and then analysed on a Pascal 240 porosimeter within the range from $0 \mathrm{MPa}$ to 200 $\mathrm{MPa} . \mathrm{N}_{2}$ sorption isotherms were obtained at $77 \mathrm{~K}$ on a Micromeritics ASAP 2020 analyser under continuous adsorption conditions. Prior to these measurements, chip samples were heated at $200{ }^{\circ} \mathrm{C}$ for $2 \mathrm{~h}$ and outgassed to $1.33 \cdot 10^{-3}$ mbar using a Micromeritics Flowprep equipment. Gas-adsorption analysis across the relative pressure range of 0.05 to 0.3 was used to determine the total specific area or Brunauer-Emmet-Teller (BET) surface area of the samples. ${ }^{18,19}$ The sample total pore volume and the micropore volume were calculated using a t-plot analysis, with the Barret-Joyner-Halenda (BJH) method employed to obtain the pore-size distribution curves. ${ }^{20}$

Table 1: Pottery samples from the archaeological site near Mošnje Tabela 1: Vzorci lončenine $z$ arheološkega najdišča pri Mošnjah

\begin{tabular}{|c|c|c|c|c|c|}
\hline \multirow{2}{*}{ Sample } & \multirow{2}{*}{$\begin{array}{c}\text { Location } \\
\text { Grid square }\end{array}$} & Type & Surface colour & \multicolumn{2}{|c|}{ Time frame } \\
\hline & & \multicolumn{2}{|c|}{ Stratigraphic unit } & \multicolumn{2}{|c|}{ Munsell colour chart } \\
\hline K1 (4254) & L10 & 187 & coarse ware & 7.5YR5/1 (gray) & 1.-3. (?) Century \\
\hline K3 (3264) & L10 & 137 & fine ware & 7.5YR6/8 (reddish yellow) & 1.-3. Century \\
\hline K6 (1722A) & N7, O7 & 162 & coarse ware & 7.5YR6/4 (light brown) & 1. -1 . half of $2^{\text {nd }}$ Century \\
\hline K7 (1909) & L9 & 196 & fine ware & 10YR4/1 (dark gray) & 1.-2. Century \\
\hline K8 (6366) & L13 & 529 & coarse ware & 10YR3/1 (very dark gray) & 1.-2. Century \\
\hline K10 (2447) & M9, N9 & 198 & coarse ware & 10YR4/1 (dark gray) & $1^{\text {st }}$ half of 1 . Century \\
\hline K12 (1688) & N7, O7 & 162 & fine ware & 5YR7/6 (reddish yellow) & 1. -1 . half of $2^{\text {nd }}$ Century \\
\hline
\end{tabular}




\section{RESULTS AND DISCUSSION}

\subsection{FTIR analysis}

On the basis of the FTIR spectra, all the analysed pottery sherds could be divided into two main groups according to the presence or absence of calcite. The obtained FTIR spectra are shown in Figures 1 and 2.

As can be seen in Figure 1, absorption bands at around $(2515,1797,1426,875$ and 714$) \mathrm{cm}^{-1}$ that are characteristic of calcite were observed in the spectra of all the Group-1 samples (K1, K6, K8, and K10), which represent calcite-tempered coarse ware. ${ }^{16}$ Another intense absorption band appears at around $1030 \mathrm{~cm}^{-1}$, indicative of clay minerals such as illite. ${ }^{9}$ The small absorption band at $1164 \mathrm{~cm}^{-1}$, the shoulder at $1080 \mathrm{~cm}^{-1}$, the doublets at $798 \mathrm{~cm}^{-1}$ and $779 \mathrm{~cm}^{-1}$, and the band at $694 \mathrm{~cm}^{-1}$, together indicate the presence of quartz in all the samples within the group.

According to the literature ${ }^{21}$, the absorption band at around $3630 \mathrm{~cm}^{-1}$ is due to hydroxyl groups that persist up to $800{ }^{\circ} \mathrm{C}$. The small absorption band at around 3630 $\mathrm{cm}^{-1}$, and which is assigned to the illite/muscovite, is clearly observed in sample K10, and slightly preserved in sample K1. This indicates that these two samples might have been fired below $800{ }^{\circ} \mathrm{C}$, as already presumed in a previous study. ${ }^{16}$ In contrast, those samples not exhibiting the absorption band at around $3630 \mathrm{~cm}^{-1}$ were likely fired to temperatures of $800{ }^{\circ} \mathrm{C}$ or above (samples K6 and K8).

As shown in Figure 2, the spectra of the Group-2 samples that represent fine ware with predominant silicate grains (K3, K7, and $\mathrm{K} 12$ ) are, besides the absence of absorption bands, characteristic of calcite, characterised by a most intense band at about $1035 \mathrm{~cm}^{-1}$, which is attributed to the $\mathrm{Si}-\mathrm{O}$ vibrations of silicate (clay) minerals. Sample K3 does not exhibit an absorption band at around $3630 \mathrm{~cm}^{-1}$, indicating a firing temperature higher than $800{ }^{\circ} \mathrm{C}$. This band is slightly preserved in samples $\mathrm{K} 7$ and $\mathrm{K} 12$, indicating a lower firing temperature for these samples. The absorption

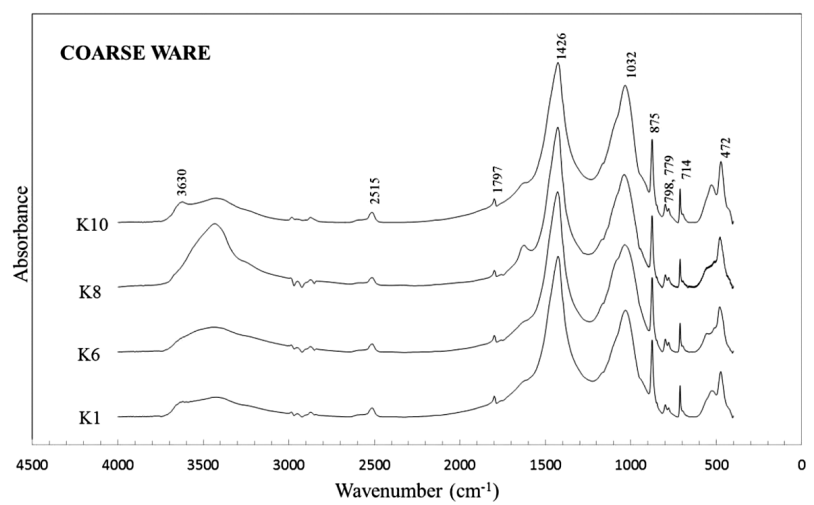

Figure 1: FTIR spectra of the calcite-tempered pottery sherds (coarse ware)

Slika 1: Spektri FTIR odlomkov lončenine z dodatkom kalcitnih zrn (groba keramika)

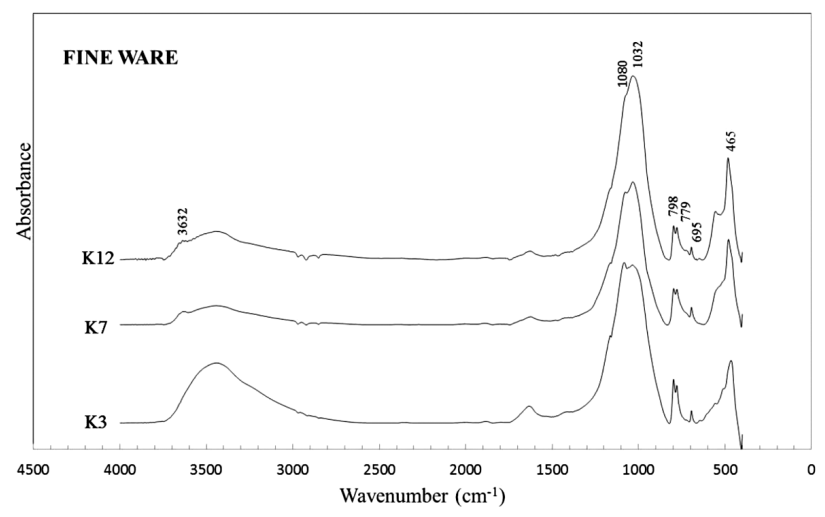

Figure 2: FTIR spectra of the pottery sherds with a predominantly fine silicate fabric (fine ware)

Slika 2: Spektri FTIR odlomkov lončenine, ki vsebujejo pretežno drobna silikatna zrna (fina keramika)

band at $1161 \mathrm{~cm}^{-1}$, the shoulder at $1080 \mathrm{~cm}^{-1}$, the doublets at $797 \mathrm{~cm}^{-1}$ and $779 \mathrm{~cm}^{-1}$, and the band at 694 $\mathrm{cm}^{-1}$, are evidence of quartz in all the samples, with levels being especially high in sample K3. Sample K3 also has an additional shoulder at $1013 \mathrm{~cm}^{-1}$, suggesting the use of a different clay than that in samples K7 and K12. Together with those at around $720 \mathrm{~cm}^{-1}$ and 646 $\mathrm{cm}^{-1}$, this band has been ascribed to feldspars previously identified in larger amounts in the same sample. ${ }^{16}$

\subsection{SEM}

The examination of the fresh fracture surfaces and the polished sections provided some insight into the microstructure of the pottery sherds. As can be seen in the SEM microphotographs in Figure 3, the differences among the coarse and fine ware were observed in terms of their pore morphology and pore volume in the matrix. Information regarding the pottery's internal morphology, which developed during the original firing in antiquity, as well as the extent of vitrification, was revealed by the analysis of freshly fractured samples, as shown in Figure 4.

The coarse ware matrix is characterised by the occurrence of elongated pores or fissures and cracks around the calcite grains (Figure 3a). Samples K1 and especially K6 contain larger amounts of non-plastic inclusions (quartz, illite/muscovite) than do samples K8 and K10. The laminar habits of the phyllosilicates (illite/muscovite) in samples $\mathrm{K} 1$ and $\mathrm{K} 6$ are still preserved, which is also in accordance with the FTIR results, as the latter spectra included an absorption band associated with the hydroxyl group. Cultrone et al. ${ }^{22}$ previously reported that samples fired at $700{ }^{\circ} \mathrm{C}$ and $800{ }^{\circ} \mathrm{C}$ still preserve the laminar habit of phyllosilicates, although muscovite crystals clearly exfoliate along basal planes, as also observed in sample K1. In this temperature range no clear evidence of sintering or partial melting should be detected, as vitrification occurs above $900{ }^{\circ} \mathrm{C}$. In addition, according to Maniatis and Tite ${ }^{11}$, low refractory non-calcareous clays fired in oxidising conditions with no 

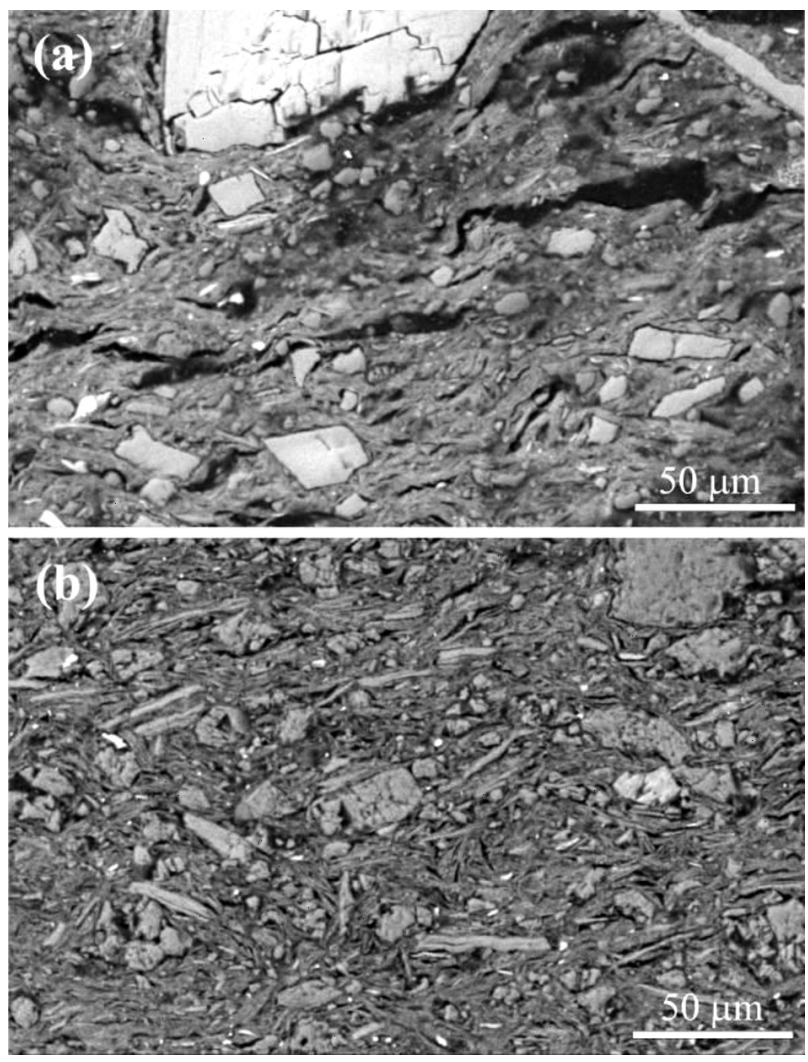

Figure 3: SEM photomicrographs of polished thin sections of pottery: a) elongated pores in sample $\mathrm{K} 8, \mathrm{~b}$ ) illite micromass in sample $\mathrm{K} 7$

Slika 3: SEM-mikrofotografija poliranih zbruskov lončenine: a) podolgovate pore v vzorcu K8, b) ilitna mikromasa v vzorcu K7

vitrification stage were fired below $800{ }^{\circ} \mathrm{C}$. Thus, samples $\mathrm{K} 1$ and $\mathrm{K} 10$ belong to the first group (NV), which contains pottery exhibiting no vitrification. Samples $\mathrm{K} 6$ and $\mathrm{K} 8$ could belong to the initial vitrification stage (IV) that is developed typically at firing temperatures in the range of $800-850{ }^{\circ} \mathrm{C}$. This is suggested by the appearance of smooth-surfaced areas and the rounded edges of the clay plates (Figure 4a).

The matrix of the fine ware samples is relatively homogenous, with an illite micromass observed in samples K7 and K12 (Figure 3b). Among the fine ware samples, the preserved laminar habits of phyllosilicates presented in samples K7 and K12 (Figure 4b) indicate that these sherds were not subject to vitrification (NV). In contrast, the rounded particle edges in sample K3 are suggestive of the initial vitrification stage (IV).

\subsection{Mercury-intrusion porosimetry}

Table 2 presents the sample parameters determined via mercury-intrusion porosimetry (total porosity, average pore diameter, bulk density and apparent density).

The porosity values range from $21.34 \%$ to $44.03 \%$. In general, the total porosity of pottery sherds with coarse inclusions is lower (21.34-30.33 \%) than that of the fine ware pottery sherds, in which the porosity ranges
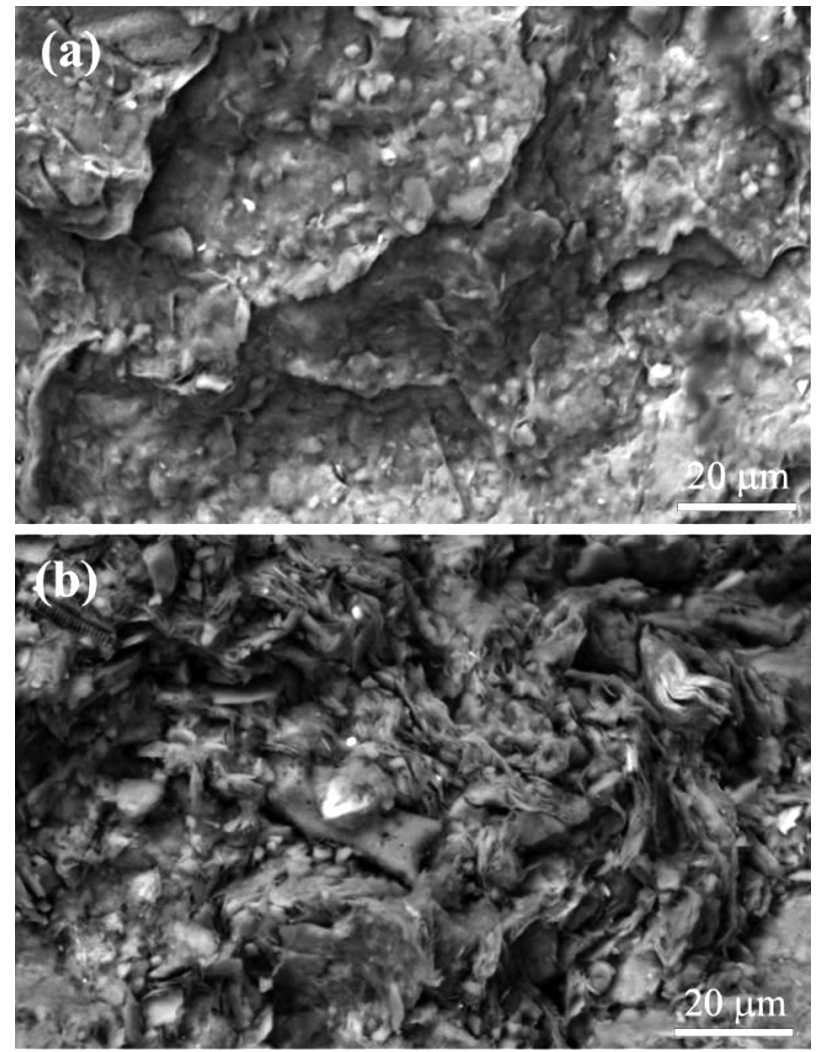

Figure 4: SEM photomicrographs demonstrating the degree of vitrification in the studied coarse ware and fine ware: a) smooth-surfaced areas could indicate initial vitrification in sample $\mathrm{K} 8$, b) preserved laminar habit of phyllosilicates indicates no vitrification in sample K12

Slika 4: SEM-mikrofotografija prikazuje stopnjo vitrifikacije pri grobi in fini keramiki: a) zaobljena površina lahko nakazuje začetno stopnjo vitrifikacije v vzorcu K8, b) ohranjena laminarna struktura filosili-

katov nakazuje, da do vitrifikacije še ni prišlo, vzorec K12

from $36.49 \%$ to $44.03 \%$. Furthermore, the average pore size diameter of the fine ware sherds is lower than that of the sherds with coarse inclusions. The sample bulk densities vary from $1.32 \mathrm{~g} / \mathrm{mL}$ to $1.99 \mathrm{~g} / \mathrm{mL}$, whereas the apparent densities range from $2.52 \mathrm{~g} / \mathrm{mL}$ to $2.68 \mathrm{~g} / \mathrm{mL}$.

Table 2: Porosity, average pore diameter, bulk density and apparent density of the investigated pottery samples

Tabela 2: Poroznost, povprečen premer por, volumenska in navidezna gostota preiskanih vzorcev lončenine

\begin{tabular}{|c|c|c|c|c|}
\hline Sample & $\begin{array}{c}\text { Porosity } \\
(\%)\end{array}$ & $\begin{array}{c}\text { Average pore } \\
\text { diameter }(\mu \mathrm{m})\end{array}$ & $\begin{array}{c}\text { Bulk den- } \\
\text { sity }(\mathrm{g} / \mathrm{mL})\end{array}$ & $\begin{array}{c}\text { Apparent den- } \\
\text { sity }(\mathrm{g} / \mathrm{mL})\end{array}$ \\
\hline \multicolumn{5}{|c|}{ Coarse ware } \\
\hline K1 & 21.43 & 5.54 & 1.98 & 2.52 \\
\hline K6 & 30.33 & 0.22 & 1.82 & 2.61 \\
\hline K8 & 21.34 & 4.60 & 1.99 & 2.54 \\
\hline K10 & 29.15 & 58.94 & 1.90 & 2.68 \\
\hline \multicolumn{5}{|c|}{ Fine ware } \\
\hline K3 & 44.03 & 0.66 & 1.32 & 2.36 \\
\hline K7 & 36.49 & 0.38 & 1.60 & 2.52 \\
\hline K12 & 37.11 & 0.37 & 1.60 & 2.54 \\
\hline
\end{tabular}

All the samples with coarse inclusions exhibit a distinctive bimodal pore distribution, which is reflected 
in a higher average pore diameter. These samples are also characterised by the presence of elongated pores in the matrix and sizeable cracks around the large calcite inclusions, as seen in SEM observations; these features thus contribute to the shift towards larger pores. Nevertheless, the main peak, with a higher intrusion, is observed at around $7.5 \mu \mathrm{m}$ to $10 \mu \mathrm{m}$ in all coarse ware samples with the exception of K10, where the distribution curve is shifted significantly to the right $(85 \mu \mathrm{m})$. The minor intrusion peak occurs at around $0.07 \mu \mathrm{m}$ to $0.15 \mu \mathrm{m}$ in samples $\mathrm{K} 8$ and $\mathrm{K} 10$, while in samples $\mathrm{K} 1$ and $\mathrm{K} 6$ this peak is shifted slightly to the right at around $0.5 \mu \mathrm{m}$. Samples K6 and K10, respectively, exhibit the lowest and highest average pore size diameters. Whereas the intrusion peaks at higher pore diameters are most probably related to the presence of fissures and pores in the matrix, the peaks at smaller pore diameters are associated with the composing clay minerals. The latter peaks occur at lower values in the group of pottery sherds containing calcite temper than in the non-tempered pottery, thus indicating the use of different types of raw clay in their manufacture. In samples K8 and K10 the minor peak is shifted to even smaller values, since these sherds were found to contain very little illite/muscovite. ${ }^{16}$ Most porosity observed before $800{ }^{\circ} \mathrm{C}$ depends on the type of clay, as well as on the size and concentration of the inclusions. ${ }^{23}$

The porosities of the pottery sherds containing fine particles are unimodally distributed, with the largest intrusions being around $0.60 \mu \mathrm{m}(\mathrm{K} 7, \mathrm{~K} 12)$ or $0.85 \mu \mathrm{m}$ (K3). While samples K7 and K12 have similar total porosities and average pore size diameters, sample K3 exhibits the highest porosity among all the samples, as well as an average pore size diameter larger than that of the other two samples. The latter were also found to have a higher percentage of phyllosilicates, as observed via SEM-EDS ${ }^{16}$, together with a different type of matrix to that seen in sample K3. The total specific surface is related to the grain size, with the smallest values found in sample $\mathrm{K} 3$.

Velraj et al. ${ }^{21}$ have previously reported that samples containing coarse particles exhibit higher porosity, the reverse of the pattern observed here. Although a high firing temperature will lead to low porosity, ${ }^{7,24}$ the fact that in the present study the porosity of the coarse ware is lower than that of the fine ware is most likely due to the type of clay used, with the former made of plastic montmorillonite-illite clays and the latter characterised by the predominance of illite, potentially mixed with other clay minerals. ${ }^{16}$

\subsection{Gas sorption}

The sample BET-specific surface area varies from $2.90 \mathrm{~m}^{2} / \mathrm{g}$ to $91.55 \mathrm{~m}^{2} / \mathrm{g}$, with the fine ware sherds characterised by significantly higher values (36.25-91.55 $\mathrm{m}^{2} / \mathrm{g}$ ) than those of the coarse ware $\left(2.90-7.97 \mathrm{~m}^{2} / \mathrm{g}\right)$ (Table 3). On the other hand, the coarse ware samples exhibit a larger average pore diameter. Two samples, K7 and $\mathrm{K} 10$, present a pore size distribution with weak maxima of approximately $4 \mathrm{~nm}$ and $20 \mathrm{~nm}$, respectively, whereas those of the other samples are either unclear or smaller than the detection limit. The volume of pores accessible to gas is larger in the case of the fine ware sherds. Similar to the previous results, the lower BET surface area of the coarse ware is the result of the presence of a coarse calcite temper. In contrast, the various fine fabrics characterising the fine ware sherds contribute to their higher BET surface areas, with sample K7 composed of a medium sand fraction ${ }^{16}$ having the lowest BET surface area, and K12 composed of a very fine sand fraction having the highest BET surface area.

All of the samples studied present a type-II physisorption isotherm characteristic of non-porous and macroporous materials. ${ }^{25}$

Table 3: Results of $\mathrm{N}_{2}$-adsorption measurements for the investigated pottery samples

Tabela 3: Rezultati $\mathrm{N}_{2}$-adsorpcijskih meritev preiskanih vzorcev lončenine

\begin{tabular}{|c|c|c|c|c|}
\hline Sample & $\begin{array}{c}\text { BET } \\
\text { surface area }\end{array}$ & $\begin{array}{c}\text { Total pore } \\
\text { volume }\end{array}$ & $\begin{array}{c}\text { Average } \\
\text { pore } \\
\text { diameter }\end{array}$ & $\begin{array}{c}\text { Micropore } \\
\text { volume }\end{array}$ \\
\hline pha & $\mathrm{m}^{2} / \mathrm{g}$ & $\mathrm{cm}^{3} / \mathrm{g}$ & $\mathrm{nm}$ & $\mathrm{cm}^{3} / \mathrm{g}$ \\
\hline Coarse ware & & & & \\
\hline K1 & 2.90 & 0.0090 & 12.41 & 0.000052 \\
\hline K6 & 4.35 & 0.0113 & 10.36 & 0.000290 \\
\hline K8 & 7.97 & 0.0090 & 12.41 & 0.000572 \\
\hline K10 & 3.78 & 0.0165 & 17.41 & 0.000050 \\
\hline Fine ware & & & & \\
\hline K3 & 86.37 & 0.0976 & 4.52 & 0.009380 \\
\hline K7 & 36.25 & 0.0022 & 4.98 & 0.002232 \\
\hline K12 & 91.55 & 0.0836 & 3.65 & 0.012577 \\
\hline
\end{tabular}

\section{CONCLUSIONS}

Samples of coarse ware and fine ware from an archaeological site near Mošnje (Slovenia), which according to previous analysis have been recognised as local or perhaps regional products, were investigated in order to characterise their porosity and estimate their firing temperature.

Based on FTIR spectra, the pottery sherds can be divided into two main groups, reflecting either the presence or absence of calcite. The firing temperature was estimated according to the presence of an absorption band at around $3630 \mathrm{~cm}^{-1}$, which is associated with hydroxyl groups persistent up to $800{ }^{\circ} \mathrm{C}$. This band was observed in two coarse ware samples and two fine ware samples, indicating that these sherds might have been fired below $800{ }^{\circ} \mathrm{C}$. In contrast, samples not exhibiting this absorption band would likely have been fired at temperatures of at least $800{ }^{\circ} \mathrm{C}$ or above.

Differences were observed among the coarse and fine ware samples in terms of their pore morphology and pore volume in the matrix, as well as the extent of the vitri- 
fication. Two vitrification stages were recognised in the studied pottery samples: no vitrification and an initial vitrification stage. These results are consistent with the obtained FTIR data, as the absence of a vitrification stage is characteristic of pottery fired below $800{ }^{\circ} \mathrm{C}$, whereas an initial vitrification stage is developed typically at firing temperatures in the range of $800-850{ }^{\circ} \mathrm{C}$.

In general, the total porosity of the pottery sherds containing coarse inclusions was lower than that of the fine pottery shards, most probably due to the plastic clay used in the former. The fine ware samples had a significantly larger BET surface area than the coarse ware samples, which is mainly related to the fabric or temper grain size.

\section{Acknowledgements}

This study was financially supported by the ARRS Program Group P2-0273.

\section{REFERENCES}

${ }^{1}$ M. S. Tite, Journal of Archaeological Method and Theory, 6 (1999) 3, 181-233

${ }^{2}$ R. Palanivel, U. Rajesh Kumar, Rom. J. Phys., 56 (2011) 1-2, 195-208

${ }^{3}$ C. Rathossi, P. Tsolis-Katagas, C. Katagas, Applied Clay Science, 24 (2004) 3-4, 313-326, doi:10.1016/j.clay.2003.07.008

${ }^{4}$ G. Barone, A. Lo Giudice, P. Mazzoleni, A. Pezzino, D. Barilaro, V. Crupi, M. Triscari, Archaeometry, 47 (2005) 4, 745-762, doi:10.1111/ j.1475-4754.2005.00230.x

${ }^{5}$ J. Barrios-Neira, L. Montealegre, L. A. López, L. Romero, Applied Clay Science, 42 (2009), 529-537, doi:10.1016/j.clay.2008.06.018

${ }^{6}$ C. M. Belfiore, M. di Bella, M. Triscari, M. Viccaro, Materials Characterisation, 61 (2010) 4, 440-451, doi:10.1016/j.matchar.2010. 01.012

${ }^{7}$ M. S. Tite, Archaeometry, 11 (1969) 1, 134-143, doi:10.1111/j.14754754.1969.tb00636.x
${ }^{8}$ R. Ravisankar, S. Kiruba, A. Chandrasekaran, A. Naseerutheen, M. Seran, P. D. Balaji, Indian Journal of Science and Technology, 3 (2010) 9, 1016-1019, doi:10.17485/ijst/2010/v3i9/29880

${ }^{9}$ G. E. De Benedetto, R. Laviano, L. Sabbatini, P. G. Zambonin, Journal of Cultural Heritage, 3 (2002), 177-186, doi:10.1016/S12962074(02)01178-0

${ }^{10}$ R. Palanivel, G. Velraj, Indian Journal of Pure \& Applied Physics, 45 (2007), 501-508

${ }^{11}$ Y. Maniatis, M. S. Tite, Journal of Archaeological Science, 8 (1981), 59-76, doi: 10.1016/0305-4403(81)90012-1

${ }^{12}$ A. M. Musthafa, K. Janaki, G. Velraj, Microchemical Journal, 95 (2010) 2, 311-314, doi:10.1016/j.microc.2010.01.006

${ }^{13}$ K. G. Harry, A. Johnson, Journal of Archaeological Science, 31 (2004), 1567-1575, doi:10.1016/j.jas.2004.03.020

${ }^{14}$ P. M. Rice, Pottery Analysis: a sourcebook, University of Chicago Press, Chicago, IL and London 1987, 584

${ }^{15}$ V. Vidrih Perko, Arheološki vestnik, 48 (1997), 341-358

${ }^{16}$ S. Kramar, J. Lux, A. Mladenović, H. Pristacz, B. Mirtič, M. Sagadin, N. Rogan - Šmuc, Applied Clay Science, 57 (2012), 39-48, doi:10.1016/j.clay.2011.12.008

${ }^{17}$ N. Rogan - Šmuc, M. Dolenec, J. Lux, S. Kramar, Environmental Earth Sciences, 71 (2014) 11, 4821-4833, doi:10.1007/s12665-0132874-1

${ }^{18}$ S. J. Gregg, K. S. W. Sing, Adsorption, surface area and porosity, 2nd ed., Academic Press, London 1982, 303

${ }^{19}$ R. W. Adamson, A. P. Gast, Physical chemistry of surfaces, Chapter 17, 6th ed., Wiley, New York 1997, 808

${ }^{20}$ E. P. Barret, L. G. Joyner, P. P. Halenda, Journal of the American Chemical Society, 73 (1951), 373-380, doi: 10.1021/ja01145a126

${ }^{21}$ G. Velraj, K. Janaki, A. Mohamed Mushafa, R. Palanivel, Applied Clay Science, 43 (2009), 303-307, doi:10.1016/j.clay.2008.09.005

${ }^{22}$ G. Cultrone, C. Rodriguez - Navarro, E. Sebastian, O. Cazalla, M. J. De la Torre, European Journal of Mineralogy, 13 (2001) 3, 621-634, doi:10.1127/0935-1221/2001/0013-0621

${ }^{23}$ M. S. Tite, Y. Maniatis, Transactions and Journal of the British Ceramics Society, 74 (1975) 1, 19-22

${ }^{24}$ M. Mureson, Materials and Structures, 6 (1973) 3, 203-208, doi: 10.1007/BF02479034

${ }^{25}$ K. S. W. Sing, D. H. Everett, R. A. W. Haul, L. Moscou, R. A. Pierotti, J. Rouquérol et al., Pure and Applied Chemistry (IUPAC), 57 (1985), 603-619 